\title{
Perbankan Islam di Indonesia: Implikasinya dengan Politik, Hukum, dan Islam
}

\author{
Naziarto. SR
}

\begin{abstract}
The appearance of Islamic Banking in Indonesia has closely correlation to the real politics and the authority of government (new order) under 'fower center' Soeharto as a President the former at that time. Because there is magnet mutually tug of role and the impact of major Moslem in politics to defend his authority. The reality of coming for /slamic banking on June in 1992 is as accommodation for economic and political dimension in New Order state by the power of Islam. The insitutution of banking acts which is valid today have not met and given the whole opportunity for dynamicization of Islamic banking in Indonesia. It is natural that to be happen because viewed from historical fact that the process of reconstructing for banking acts was done in abnormal era.
\end{abstract}

\section{Pendahuluan}

Krisis perbankan nasional yang terjadi akhir-akhir ini telah memberi ibroh (pelajaran sekaligus nasihat) kepada kalangan dan pengambil kebijakan perbankan di tanah air. Ibroh itu tak lain adalah perlunya segera dilakukan perbaikan dan penyempurnaan terhadap sistem perbankan .konvensional. Di samping itu, perlu diformalisasi dan disosialisasikan sistem perbankan alternatif yang dikelola secara amanah, halal,: profesional, menguntungkan, serta rentan menghadapi badai krisis. Sistem perbankan altematif itu, tak lain adalah sistem perbankan yang dilakukan secara Islami, atau dengan kata lain perbankan Islam.

Hadimya perbankan Islam di Indonesia ditandai dengan kehadiran Bank Muamalat Indonesia (BMI) dekade tahun 1992. Eksisitensinya, akhir-akhir ini telah membawa pengaruh terhadap perkembangan dunia perbankan di Indonesia. Banyak kalangan dan pengamat perbankan yang melirik sistem operasional perbankan yang didasari atas ajaran agama Islam itu.

Adanya perbankan Islam di Indonesia sekarang ini, tidak terlepas dari kondisi riil politik dan kekuasaan pemerintahan (Orde Baru) di bawah 'fower center' Soeharto selaku Presiden ketika itu. Terjadi 'magnit' tarikmenarik peran dan pengaruh umat Islam mayoritas ke kancah politik untuk mempertahankan kekuasaannya. Realitas hadirnya perbankan Islam di Juni 1992 itu merupakan wujud dimensi ekonomi-politik akomodasi negara Orde Baru dengan kekuatan Islam. Sementara dimensi yang demikian, konteknya dengan lembaga keuangan di Indonesia, khususnya dunia 
perbankan tidak dapat terlepas dari dimensi politik dan hukum. Bagaimana dimensi tersebut, dan peran apa yang dimainkan umat Islam?

\section{Konvergensi Politik Umat Islam terhadap Perbankan Islam di Indonesia}

Tulisan Didik J. Rachbini, "Assalamu'alaikum, Kiyai Masuk Bank", yang dimuat Info Bank, ${ }^{1}$ merupakan salah satu contoh pengaruh kebangkitan Islam di Indonesia dalam soal hubungan antara Islam dan negara. Bachtiar Effendy menyebut perkembangan politik Indonesia ini secara spesifik sering disimpulkan dalam frase-frase pendek: "akomodasi negara terhadap Islam", "konvergensi Islam dan negara" atau "integrasi ke-Islaman dan keindonesiaan". ${ }^{2}$ Sebab, suasana politik di Indonesia, ketika itu beda dengan realitas sebelumnya, yang ditandai oleh adanya ketegangan timbal-balik (mutual animosity). Corak hubungan yang berkembang sejak tahun 1980-an dianggap memberi harapan bagi komunitas Islam untuk tidak lagi berada di pinggiran.

Ada dua artian penting yang pantas untuk dicatat sehubungan dengan perkembangan politik Islam di Indonesia. Pertama, pada tataran simbolis hal tersebut dapat dianggap sebagai isyarat bahwa persoalan 'ideologi' antara Islam dan negara sudah selesai. Paling tidak, jurang ideologis yang dulu pernah melebar telah terciutkan. Kedua, fenomena di atas menunjukkan secara jelas, bahwa telah terjadi perubahan pelakuan (reversed treatment) dari negara terhadap komunitas Islam. Kepentingan Islam mulai semakin terakomodasikan. Termasuk dalam konteks kedua ini adalah kepentingan politik Islam, khususnya kebutuhan para pemikir dan aktivisnya akan pengaruh (leverage) struktural atau akses kekuasaan.

Hubungan antara Islam dan negara yang dulu bersifat 'bermusuhan' (hostile) telah membawa implikasi-implikasi tertentu yang kurang mengenakkan. Menurut Bachtiar Effendy ${ }^{3}$, secara politis hal itu telah-antara lainmenempatkan Islam politik (political Islam) pada posisi pinggiran atau minoritas dalam dinamika politik nasional. Bahkan, sementara kalangan Islam sendiri beranggapan, bahwa mereka telah diperlakukan sebagai 'kucing kurap' oleh negara. Hal yang paling menyedihkan adalah komunitas politik Islam sering menjadi sasaran empuk bagi sebuah kecurigaan, sebagai kelompok anti ideologi Pancasila. Dalam situasi semacam ini, mudah ditebak bahwa leverage struktural mereka sangatlah terbatas. Kalau tidak sama sekali tertutup.

'Lihat Didik J.Rachbini. “Assalamu'alaikum, Kiyai Masuk Bank. ${ }^{i}$ nfo Bank No. 124. April 1990. HIm.7.

${ }^{2}$ Bachtiar Effendy. 2000. Repolitisasi Islam, Pernahkah Islam Berhenti Berpolitik. Bandung: Mizan. HIIm. 160. Banyak indikator, baik yang bersifat struktural, infrastruktural, maupun kultural, yang dapat dijadikan dasar bagi penilaian seperti itu. Termasuk dalam hal ini adalah disahkannnya Undang-undang Pendidikan Nasional (UUPN) dan Undang-undang Peradilan Agama (UUPA), disusunnya Kompilasi Hukum Islam, dirumuskannya kebijakan baru tentangjilbab, dikeluarkannya SKB tentang Bazis, dan dalam tatanan ekonomi didirikannya perbankan Islam melalui lembaga Bank Muamalat Indonesia (BMI), dan dibentuknya ICMI.

3lbid. HIm 161. 
Konteksnya dengan kekuatan umat Islam; dan konvergensi Islam dengan negara dalam dimensi ekonomi-politik terjadi dalam hal masalah lembaga keuangan perbankan; yakni tentang bunga bank. Perdebatan mengenai topik bunga perbankan yang tetap kontroversial dalam sejarah modern Isiam di Indonesia memberi nuansa baru bagi politik umat Islam terhadap perbankan Islam. Sebagai contoh, dari survei terhadap 479 orang penduduk Jakarta terhadap bunga bank menunjukkan, hanya 34 persen yang menyetujui bunga bank. Sisânya, 25,9 persen kurang setuju, dan hampir 40 persen menyatakan tidak setuju atau sangat tidak setuju dengan sistem bunga yang diterapkan perbankan. ${ }^{4}$

Tidaklah mengherankan, jika salah satu pengaruh yang diakibatkan oleh kebangkitan Islam di Indonesia sejak tahun 1980-an, adalah makin mengentalnya seruan akan perlunya pembentukan perbankan Islam yang tidak menerapkan bunga dalam bentuk yang bagaimanapun. Seruan ini diperkuat pula dengan berbagai peristiwa di belahan dunia internasional, dengan berdirinya Republik Islam Iran yang tidak satupun mengoperasikan bank dengan sistem bunga. Pengaruh besar negara Arab Saudi pada tahun 1973 membentuk bank yang beroperasi tanpa bunga, yakni didirikannya Islamic Development Bank (IDB). Indonesia salah satu negara yang ikut mendukung dan menandatangani kesepakatan pembentukan Islamic Development Bank itu.
Kloplah sudah, akhirnya Indonesia mendapat kucuran pinjaman dari IDB melalui pintu Departemen Keuangan. Sebab, IDB tidak membuka cabang di Indonesia. IDB menyediakan modal maupun masukan teknis kepada negara-negara yang memperlihatkan minat untuk mendirikan perbankan Islam di negerinya.

Politik kebijakan perbankan di Indonesia, pada ujung-ujungnya merupakan suatu terobosan yang memungkinkan berdirinya perbankan Islam yang disetujui oleh pemerintah. Semua ini terjadi akibat dari kebangkitan Islam di Indonesia dan perubahan sikap pemerintah terhadap Islam. Untuk merealisasi kebangkitan umat Islam itu, MU! sebagai salah satu lembaga Islam yang didukung oleh pemerintah memainkan peranan penting dalam tahap awal pendirian perbankan Islam di Indonesia.

Sejalan dengan semakin tipisnya kekhawatiran pemerintah terhadap Islam religius, dan makin tampaknya hasit-hasil dari kebangkitan Islam, beberapa ulama dari MUI mulai mengkaji kemungkinan untuk mengajukan kembali rencana pendirian perbankan Islam. Akhirnya pada 19-20 Agustus 1990, MUI diberi restu oleh pemerintah untuk mengadakan lokakarya membahas "Masalah Bunga dan Bank" di Cisarua, Bogor. Lokakarya ini dihadiri kalangan pejabat Bank Indonesia, Dewan Moneter, Departemen Keuangan. Kebanyakan pengamat kala itu mengatakan, bahwa kemungkinan besar

${ }^{4}$ Lihat DidikJ. Rachbini. Op.Cit. HIm.7. 
presiden Soeharto sendiri telah memutuskan untuk meneyetujui rencana pembentukan perbankan Islam itu.

Dengan langkah hati-hati dan menunggu waktu yang tepat guna menghindari munculnya penentangan dari kalangan militer, ${ }^{5}$ MUI-pun: mengadakan Kongres Nasional ke-IV sebagai follow up dari lokakarya untuk menyetujui dibentuknya perbankan Islam. Suatu tim perbankan Islam dibentuk MUI diketuai oleh DR. Ir. Amin Aziz dibantu tim hukum ICMI diketuai oleh Drs. Karnaen Parwataatmaja, MPA. ${ }^{6}$

Konvergensi Islam dengan negara dalam dimensi ekonomi-politik yang terJadi di Indonesia banyak melibatkan peran beberapa tokoh secara bersamaan. Upaya yang dilakukan MU! untuk mendirikan perbankan Islam persis bersamaan dengan upaya tokohtokoh kekuatan Islam; baik itu oleh para pejabat maupun non pejabat yang duduk di pemerintahan yang pro Islam untuk mendirikan ICMI. Bahkan, dalam beberapa hal, dua upaya hemogenitas (ekonomi-politik) ini saling terkait. Beberapa tokoh yang aktif dalam pembentukan ICMI juga masuk dalam panitia pengarah pembentukan Perbankan Islam (BMI). Beberapa menteri kabinet membujuk Presiden Soeharto untuk mendukung pembentukan ICMI dan Perbankan Islam tersebut. Kenyataanya, bahwa Presiden Soeharto mengabaikan kalangan militer dan para penasihatnya dari kalangan teknokrat, dan justru mendukung pendirian perbankan Islam dan ICMI. Atas dukungan presiden tersebut, banyak pengamat beranggapan telah terjadi indikasi perpecahan di kalangan pemerintahan.

Sementara dari kalangan pengamat muslim melihat kedua perkembangan tersebut sebagai bukti makin terbukanya sikap pemerintah terhadap umat Islam, sesuatu yang tidak ada presedennya sepanjang sejarah Orde Baru. ${ }^{7}$ Sikap Presiden Soeharto yang melakukan akomodasi secara proporsional terhadap pikiran-pikiran seperti itu, penting bagi negara. Terutama akan meningkatkan legitimasi kultural negara. Kalau legitimasi struktural suatu negara dapat diperoleh dengan seperangkat kegiätan pembangunan politik dan ekonomi, maka legitimasi kultural (hanya akan) didapatkan melalui tindakan

${ }^{5}$ Kalangan militer terutama tokoh senior di Angkatan Darat ketika itu kurang mendukung terbentuknya perbankan Islam. Bahkan terjadi tarik-menarik antara senioritas yang berpengaruh di Angkatan Darat, dan Badan Intelejen serta beberapa teknokrat sekuler di Departemen Keuangan dengan menteri yang muslim duduk di jajaran kabinet terhadap rencana pendirian perbankan Islam dan pendirian Ikatan Cendekiawan Muslim Indonesia (ICMI). Mereka itu secara pribadi menentang pembentukan perbankan Islam dan rencana pembentukan ICMI, karena memandang sebagai konsesi berbahaya bagi sektarianisme primordial. Lihat, RobertW. Hefner, "Islamisasi Kapitalisme: Tentang pembentukan Bank Islam Pertama di Indonesia", dalam Mark R. Woodward, (ed). 1998. Jalan Baru Islam, Memetakan Paradigma Mutkahir Islam Indonesia. Bandung: Mizan. Hlm. 264-265.

'Lihat Aminuddin. 1999. Kekuatan Islam dan Pergulatan Kekuasaan di Indonesia, Sebelum dan Sesudah runtuhnya Rezim Soeharto. Yogyakarta: Pustaka Pelajar. HIm. 285.

${ }^{7}$ Kelompok yang memandang demikian di antaranya adalah. M. Dawam Rahardjo, Imanuddin Abdurrahim, Wardiman Djojonegoro. Lihat, Mark R. Woodward. Ibid. HIm. 266. 
akomodasi terhadap kepentingan sebagian besar masyarakat. Dalam konteks Indonesia, hal itu berarti keharusan untuk mengakomodasi kepentingan umat Islam secara memadai. Tindakan itu secara substansial-materiel terwujud dalam bentukbentuk akomodasi (misalnya disahkannya UUPA, berdirinya BMI dàn ICMI) lebih dimaksudkan untuk 'memfasilitasi', bukan 'mewajibkan' umat Islam dalam menjalankan ajaran agamanya. Hal yang demikian dalam frame politik, hendaknya dilihat dalam perspektif penjabaran konsep 'Indonesia bukan negara agama (theocratic state), tapi juga bukan negara sekuler. ${ }^{8}$

Realitas perubahan politik Indonesia yang berimplikasi dengan nuansa Islam sebagai agama dan mayoritas, seakan-akan mendapat dukungan penuh dari Presiden Soeharto. Apakah benar? Jika demikian, apa yang mendorong Presiden Soeharto yang akhimya berdiri di pihak para aktivis muslim?

Menurut pengamatan banyak pejabat tinggi, Presiden Soeharto tidak menyadari implikasi politik kebangkitan Islam yang melanda masyarakat Indonesia, khususnya kalangan kelas menengah perkotaaan. Pilihan waktu (timing) turunnya keputusan presiden untuk mendukung perbankan Islam atau (BMI) ${ }^{9}$ tampak terlihat secara langsung dipengaruhi oleh datangnya masa pemilihan anggota MPR (1992) dan presiden (Maret 1993). Sekalipun sepanjang tahun 1991 dan 1992 Presiden Soeharto cenderung tidak menyatakan secara terang-terangan, bahwa ia mengincar jabatannya untuk kelima kalinya. Namun, ia berulang kali membuat isyarat tak langsung, bahwa ia masih menginginkannya.

Didorong oleh ketidaksukaan terhadap sikap Presiden Soeharto yang enggan mundur itu, beberapa kalangan di jajaran ABRI berusaha memobilisasi oposisi terhadap presiden. Sehingga memicu perselisihan di tubuh elite yang belum ada presedennya dalam sejarah Orde Baru. ${ }^{10}$ Dalam konteks itulah Presiden Soeharto memutuskan untuk merangkul umat Islam sebagai salah satu strategi untuk mendukung pemerintahan dan kekuasaannya.

Di samping kendala-kendala yang bersifat politik upaya mendirikan perbankan Islam juga menghadapi tantangan finansial. Untuk memenuhi persyaratan perbankan yang ditetapkan oleh Departemen Keuangan, pihak penyelenggara harus menyediakan dana Rp.10 miliar untuk mendapat izin beroperasi. Padahal kala itu, angka yang demikian bukanlah suatu jumlah yang sedikit. Lagi-lagi dukungan Presiden Soeharto terbukti amat menentukan pada persoalan dana ini. Dalam rangkaian peristiwa yang dirancang secara berhati-hati, panitia yang ditugaskan untuk

${ }^{8}$ Bandingkan dengan Muhamad Tahir Azhari. 1992. Negara Hukum, Suatu Studi Tentang PrinsipPrinsipnya Dilihat Dari Segi Hukum Islam, Implimentasinya Pada Periode Negara Madinah dan Masa Kini. Jakarta: Bulan Bintang. HIm. 145-150.

${ }^{9}$ Presiden Soeharto berkenan menerima Tim MUI pembentukan Perbankan Islam di Istana Negara pada tanggal 27 Agustus 1991

${ }^{10}$ Lhat R. William Liddle. 1992. "Indonesia's Democratic Past and Futer." Comparative Politics 24, No. 8. Tanggal 9 Nopember 1992. Hlm.455-457. 
menjajaki kemungkinan pembentukan perbankan Islam berkunjung ke Presiden Soeharto pada 27 Agustus 1991. Panitia pembentukan perbankan Islam didampingi oleh beberapa menteri kabinet, ulama dari MUI, dan para pejabat yang terkait dengan rencana bakal pembentukan ICMI.

Presiden Soeharto telah diberi tahu mengenai isi proposal panitia itu jauh-jauh hari sebelum pertemuan berlangsung. Presiden pun menanggapi usulan pembentukan perbankan Islam sangat antusias, dan menawarkan untuk menyediakan modal sebesar Rp.50 juta dari kantong pribadi sebagai modal awal. Hal yang mengejutkan, bahkan tidak terpikirkan oleh kalangan panitia pembentukan perbankan Islam adalah Presiden Soeharto menyetujui digunakan dana Yayasan Amal Bhakti Muslim Pancasila" sebesar Rp 3 miliar yang dipersyaratkan untuk mendapatkan satu dari dua izin operasi perbankan Islam dengan tanpa bunga dan tanpa batas waktu pengembalian pinjaman. Selain itu beliau bersedia dicantumkan namanya sebagai pemrakarsa perbankan Islam. Presidenpun berjanji akan berupaya untuk memperoleh sisanya sebesar Rp.7 miliar. Langkah itu akan dilakukan dengan cara mengadakan pertemuan pada tanggal 3 Nopember 1991 dengan para pejabat pemerintah dan warga negara Indonesia yang kaya (konglomerat) Jawa barat untuk membeli saham Bank Muamalat Indonesia.

Dukungan presiden terhadap 'proyek' aspirasi umat lslam ini semakin membesar. Sambutan dari kalangan muslim semakin menguat. 'Nama' Presiden Soeharto secara pribadi semakin terhormat di mata umat muslim Indonesia. Demikianpun dengan ICMI yang sudah terbentuk melalui ketuanya BJ.Habibie sangat mendukung pembentukan perbankan Islam ini yang berupaya memobilisasi dana tambahan dengan cara mengundang 100 orang pengusaha kaya (konglomerat) yang selama ini dikenal sebagai 'pengusaha-klien' istana Presiden dan birokrasi di Hotel Syahid milik Sukamdani Sahid Gitosardjono pada 13 Oktober 1991. Para pengusaha ini diminta untuk membeli saham pendiri (founding shares) di BMI. Delapan puluh tujuh dari seratus orang yang diundang, hadir dalam acara tersebut. Di antara para pengusaha yang hadir terdapat nama Abu Rizal Bakrie, Fadel Muhammad, Syukamdani Sahid Gitosarjono, Ponco Sutowo dan Bob Hasan. Akhirnya terkumpul dana sebesar Rp.86 miliar untuk pembelian saham tersebut. Hanya dalam waktu enam minggu pertama setelah disetujui berdirinya perbankan Islam, BMI mampu memobilisasi jumlah dana yang cukup mencengangkan, yakni sebesar Rp.110 miliar. $^{12}$ Sehingga

"Sebuah Yayasan yang didirikan Presiden untuk membantu pembangunan Masjid dan kegiatan dakwah.

${ }^{12}$ Angka itu tercatat sebagai modal terbesar dalam sejarah perbankan setelah dikeluarkannya:Pakto '88 oleh pemerintah dan diberlakukannya kebijakan uang ketat (Tigh Money Policy). Bahkan Sukamdani.Sahid Gitosardjono seorang pengusaha perhotelan terkemuka mengatakan, bahwa pengumpulan dana perbankan (BMl) kala itu adalah salah satu rekor pengumpulan modal bank tercepat. Lihat Warta Ekonomi. "Mulus Bagai Jalan Tol." Tanggal 28 Oktober 1991. 
menjadikannya salah satu perbankan terbesar yang 35 dari sekitar 56 perbankan Islam yang ada di seluruh dunia: ${ }^{13}$

Meski membawa hasil yang mengesankan, upaya di atas tak terlepas dari kontroversi. Dari dana $\mathrm{Rp} 10$ Miliar yang disediakan Presiden Soeharto, sebanyak Rp 2 miliar di antaranya disediakan oleh pejabat pemerintah yang mengelola Sumbangan Dermawan Sosial Berhadiah (SDSB) kala itu. SDSB merupakan semacam permainan judi legal yang didukung pemerintah dan dikecam keras oleh kaum muslim Indonesia. Bahkan Majelis Ulama Indonesia (MUI) sendiri menentangnya. ${ }^{\cdot 14}$

Banyak pemimpin muslim yang mengkritik presiden secara langsung, dan ada juga yang secara pribadi percaya, bahwa dana sebesar Rp 2 Miliar dari SDSB itu jelas dimaksudkan untuk dan atau sebagai upaya membantu mengesahkan lembaga yang masih kontroversial itu. Sepuluh hari setelah menerima dana itu, para pejabat bank berupaya keras untuk menegaskan, bahwa mereka telah mengembalikan dana SDSB itu. Sikap pengembalian dan penolakan dana yang disuplai Presiden Soeharto itu, dilihat dari tata krama politik Indonesia kala itu, merupakan penegasan yang sungguh berani dari moralitas dan independensi umat Islam.
Pro dan kontra historis seputar pendirian perbankan Islam di Indonesia terus bergulir, meskipun mungkin hal itu sebagai 'pemanis' dan dapat dipetik sebagai hikmah bagi kekuatan umat muslim Indonesia sekarang ini dan masa mendatang. Salah satu contoh lain 'pemanis' kontroversial itu adalah munculnya isu Bob Hasan sebagai pembeli terbesar 'saham pendiri' (founding shares). Dia. tampil sebagai pemilik saham terbesar; yakni Rp 25 miliar.

Terkabarnya Bob Hasan pemilik saham terbesar ini segera mengundanig reaksi dari para pengamat politik maupun agama di tanah air. Mereka menyesali kenyataan itu, bahwa sebuah lembaga keuangan seperti bank yang dirancang untuk memenuhi kebutuhan para pengusaha 'pribumi' kecil dan menengah berada di bawah kontrol seorang konglomerat yang sekalipun muslim tapi keturunan Cina. 'Job' dari kalangan pengamat yang kurang setuju dengan pemilik founding shares ini, dibela oleh para promotor acara pengumpulan dana, terutama dari kalangan $\mathrm{ICMl} .^{15} \mathrm{Tapi}$, kesan yang ditangkap oleh banyak pengamat lalah perbankan Islam (BMI) kala itu tak lain adalah contoh kolaborasi Cina dan pemerintah. Para promotor pendukung pendirian perbankan Islam itu menyatakan, bahwa saham publik yang lebih murah

${ }^{13}$ Lihat, Robert W. Hefner. 'Islamisasi Kapitalisme: Tentang pembentukan Bank Islam Pertama di Indonesia", dalam Mark R. Woodward, (ed). 1998. Jalan Baru Islam, Memetakan Paradigma Mutkahir Islam Indonesia. Bandung: Mizan. Hlm.268.

${ }^{14}$ Lihat. "Ganjalan pada Rp. 110 Miliar." Editor 5, No.9, Tanggal 16 Nopember 1991. HIm. 57-58.

${ }^{15} \mathrm{ICMl}$ memainkan peranan penting dalam pembentukan perbankan Isiam di Indonesia. Setidaknya yang perlu di catat dalam hal ini. Pertama, ICMI berperan dalam melempangkan jalan pedirian bank tanpa bunga itu. Kedua, para perintis pendirian perbankan Islam mengandalkan lobby yang sangat intensif terhadap para pejabat pemerintah, terutama pemegang kunci kebijakan moneter-kebanyakan dilakukan oleh orang-orang ICMI. 
nantinya akan dijual kepada seluruh umat Islam di Jawa Barat.

Kontroversi lain yang muncul dan paling serius terjadi seputar berdirinya perbankan islam di Indonesia, adalah hadirnya oposisi dari sebagian kalangan ABRI. Para pejabat militer terkejut oleh pengumuman Presiden Soeharto yang tiba-tiba mengenai dukungannya terhadap pembentukan perbankan Islam pada Agustus 1991. Kalangan ABR! ini tetap menginginkan dan mengharapkan Presiden Soeharto mempertahankan kebijakan Orde Baru yang telah lama diputuskan, kendati tak tertulis bahwa, perbankan Islam tidak diperlukan dan hanya akan memperkuat kepentingankepentingan sosial yang 'sektarian' dan 'primordial!. ${ }^{16}$ Sejalan dengan kalangan teknokrat liberal di tubuh pemerintahan, banyak perwira militer yang khawatir, bahwa pembentukan perbankan Islam hanya akan mendorong kaum muslim untuk mengecam perbankan konvensional-sesuatu yang hanya akan merongrong salah satu institusi ekonomi Orde Baru yang paling penting. Di mata para kritikus ini, pemerintah seharusnya berusaha membawa umat Islam masuk ke dalam sistem perbankan konvensional, bukan memisahkannya dalam sebuah sektor ekonomi yang tersendiri. Bahayanya kalau langkah ini dilaksanakan oleh pemerintah adalah institusi masyarakat Indonesia akan terbelah berdasarkan garis etnis, seperti yang terjadi di Malaysia. Realitasnya apa yang dikhawatirkan oleh kalangan teknokrat ekonomi pemerintah dan kalangan militer terhadap terbelahnya garis etnis itu-tidak terbukti.

Ada dua hal yang membuat pengaruh Presiden Soeharto dalam proses pendirian perbankan ini menjadi vital. Pertama, ide mendirikan perbankan yang berdasarkan syariat Islam (tanpa bunga) kemungkinan besar mengalami kesulitan permodalan. Sebab, banyak pengusaha besar lebih tertarik menanamkan investasinya pada perbankan konvensional yang lebih menjanjikan prospek keuntungan dari pada perbankan tanpa bunga dengan asas kehati-hatian ekstra tinggi. Apalagi hingga awal dekade 1990-an konglomerat di Indonesia hampir seluruhnya 'pengusaha-klien' istana yang didominasi oleh kelompok non-pri dan juga non-muslim.

Kedua, berbagai pejabat perbankan dan moneter Kabinet Pembangunan IV kala itu masih didominasi kelompok non-muslim. Hal ini merupakan faktor kondisi subjektif yang memiliki potensi menjadi trouble maker. Indikasi dari dominannya kelompok non muslim dalam kebijakan perekonomian dan keuangan waktu itu bisa dilihat dari merebaknya istilah trio RMS (Radius, Moy dan Sumarlin), tiga pejabat tinggi negara yang terkait dengan ekonomi, perbankan dan keuangan..$^{17}$

Implikasinya perbankan Islam dengan hukum dạn umat Islam menunjukkan pengaruh yang cukup besar pada saat pendiriannya maupun perkembangannya. Realitas ini terlihat dari analisis SWOT (Strengh, Weakness, Opportunity, and Threath) Tim perbankan MUI. Tim ini

${ }^{16}$ Robertr W. Hefner. Op.Cit. HIm. 270

"Bandingkan dengan Aminudin, Kekuatan Islam dan Pergulatan Kekuasaan di Indonesia, Sebelum dan Sesudah Runtuhnya Rezim Soeharto. Op.Cit. HIm. 284. 
mengidentifikasi ada dua ancaman yang mungkin dihadapi dalam mewujudkan berdirinya perbankan Islam. Pertama, pengoperasian perbankan Islam dikait-kaitkan dengan fanatisme agama. Akan ada pihak yang menghalangi pendirian perbankan Islam itu, semata-mata karena tidak suka akan kebangkitan umat Islam dari keterbelakangan ekonominya. Mereka tidak mau tahu, bahwa perbankan Islam akan bermanfaat kepada semua orang. Isu eksklusivisme ataupun SARA mungkin dilontarkan untuk mencegah berkembangnya perbankan Islam secara luas. Kedua, mereka yang merasa terusik kenikmatannya yang selama ini telah mengeruk kekayaan rakyat yang beragama Islam melalui sistem perbankan konvensional.

Munculnya perbankan Islam yang menuntut pemerataan yang lebih adil akan dirasakan sebagai ancaman terhadap status quo yang telah dinikmati selama puluhan tahun. Mereka akan'menghambat pendirian perbankan Islam dengan membenturkan pada perangkat peraturan perundangundangan perbankan yang berlaku. Pada waktu itu, hukum perbankan ${ }^{18}$ tidak mengizinkan beroperasinya perbankan tanpa bunga atau sesuai dengan syariat Islam.
Meski ancaman kekhawatiran itu ternyata tidak sepenuhnya terbukti, namun Menteri Agama (Menag) Munawir Sjadzali sempat pesimis ketika tim perbankan MUI melakukan audiensi dengannya. Kendati demikian, Menag tetap memberi green light pendirian perbankan Islam. Sehingga tim pembentukan perbankan Islam MUI semakin bersemangat untuk melobby para pejabat pemerintah lainnya. Para pejabat yang dihubungi kala itu adalah Dirjen Moneter, Oskar Surjạatmadja; Menmud Keuangan, Nasruddin Sumintapura; dan Menteri Perdagangan, Arifin Siregar. Menteri yang paling antusias menyambut kehadiran perbankan Islam kala itu adalah Menristek, BJ.Habibie. ${ }^{19}$

Kepastian adanya perubahan hukum perbankan yang mulai menjurus kepada sistem perbankan Islam, diketahui setelah tim pembentukan perbankan MUI beraudiensi dengan Menteri Sekretaris. Negara (Mensesneg) Moerdiono. Sebab, pemerintah telah mengajukan Rencana Undang-Undang Perbankan ke DPR. Salah satu pasal dalam rencana undang-undang: :

itu mengidentifikasikan, bahwa adanya sistem pembagian keuntungan. ${ }^{20}$ Konsekuensinya, berarti RUU perbankan yang baru itu disetujui

18UU Pokok Perbankan No.14 tahun 1967 Tentang Perbankan, tidak mengizinkan beroperasinya bank tanpa bunga kredit.

${ }^{19} \mathrm{ICMl}$ membentuk Tim ahli yang diketuai Prof. DR. Emil Salim untuk kelancaran bedirinya perbankan Islam di Indonesia. Tim yang dibentuk itu ada tiga kelompok, yakni tim hukum, tim mobilisasi dana, dan tim ahli.

20Dalam RUU'ini, Moerdiono menyebutkan Pasal 1 ayat (17) yang berbunyi: "Pelunasan utang setelàh jangka waktu yang tertentu dapat disertai dengan bunga atau pembagian hasil keuntungan". Akhimya, dalam UU Perbankan No.7 Tahun 1992, bunyi Pasal tersebut diubah pada diktum Pasal 1 (ayat). 12 yang berbunyi: "Kredit adalah penyediaan uang atau tagihan yang dapat dipersamakan dengan itu berdasarkan persetujuan atau kesepakatan pinjam meminjam antara Bank dengan pihak lain yang mewajibkan pihak peminjam untuk melunasi utangnya setelah jangka waktu tertentu dengan jumlah bunga, imbalan atau pembagian bagi hasil. 
oleh rapat pleno DPR-RI pada bulan Pebruari 1992 semakin mengabsahkan dan memperkokoh perbankan Islam dalam sistem perbankan nasional.

Kendala dari segi hukum pendirian perbankan Islam adalah terjadinya benturan dengan UU No.14 tahun 1967, yang melunak setelah terjadinya deregulasi perbankan pada tahun 1983. Deregulasi ini memberi kebebasan pada bank untuk menentukan suku bunganya sendiri. Dengan demikian, perbankan Islam secara tidak langsung dapat béroperasi asalkan mencantumkan bunga nol persen (zero interest).

Ada yang menarik saat penandatanganan Akte Notaris pendirian Perbankan islam. Peran kekuatan umat Islam pada saat itu betul-betul menjadi modal dalam kekuatan politik maupun hukum. Di hadapan Notaris, ketika 145 orang pendiri perbankan Islam (BMI) sempat tertunda melakukan penandatanganan. Akibat perlu tidaknya pencantuman kata: "bahwa pemegang saham pendiri BMI warga negara Indonesia yang beragama Islam". Setelah berdialog selama 15 menit, akhimya disepakati kalimat itu tetap dicantumkan. Dalam surat akta pendirian perbankan Islam ini (BMI) menyebutkan modal dasar Rp 500 Miliar, dan modal setor Rp 100 miliar. Padahal target semula hanya Rp 10 miliar hingga 30 miliar. ${ }^{21}$

Walhasil, kini perbankan Islam telah berdiri dengan nama Bank Muamalat Indonesia (BMI). Puluhan perbankan konvensional lainnya membuka Islamic window, bahkan membuka cabang tersendiri perbankan Islam. Terlepas bagaimana perjalanan kini dan selanjutnya, yang jelas perbankan yang mendasarkan dirinya berasas Islam begitu istimewa. Sebab, jika dalam dua dekade pertama, segala pendirian institusi yang memiliki kekuatan syariat Islam selalu menjadi sumber kecurigaan pemerintah terhadap Islam. Tetapi dalam kasus pendirian perbankan Islam ini, negara memberikan dukungan penuh. Bahkan pemegang sahamnya, selain mantan Presiden Soeharto dān mantan wakil Presiden Soedharmono, juga terdapat tak kurang dari sepuluh menteri dan pengusaha besar atau 'pengusaha-klien' negara ikut memiliki saham BMI.

Dari rentetan lika-liku pendirian perbankan Islam di Indonesia sebagaimana dikemukakan di atas, ada implikasi dengan motif ekonomipolitik negara (Presiden Soeharto) ketika itu. Paling tidak, sejak awal 1982-an potret perekonomian Indonesia banyak diwarnai kesuraman, akibat makin langkanya dana investasi pembangunan, baik bersumber dari APBN maupun dari penanaman modal swasta domestik dan luar negeri. Demikianpun dengan kelesuan pasar dunia akibat membanjirnya minyak bumi di pasaran dunia yang disuplai oleh negara-negara non OPEC dari laut Utara, Mexico dan beberapa negara sosialis yang telah menekan turunnya harga minyak $_{1}^{22}$ sehingga menjurus terjadinya resesi dunia ketika itu.

Sehubungan dengan kondisi dan perkembangan perekonomian itu, pemerintah

${ }^{21}$ Pelita. "PT Bank Muamalat Indonesia Resmi Dibentuk dengan Modal Rp. 500 miliar." 2 Nopember 1991.

22Tahun 1982 OPEC membakukan harga minyak pada tingkat US $\$ 34$ per barel menjadi kurang dari $\$ 10$ pada pertengahan 1986. 
Indonesia telah melakukan serangkaian kebijakan ekonomi dengan melakukan penghematan dan pengurangan anggaran belanja, reformasi perpajakan, reorganisasi bea cukai, reformasi fiscal, moneter dan administrasi pemerintahan dengan semangat "deregulasi dan debirokratisasi. ${ }^{23}$ Konteksnya dengan perbankan Islam ketika itu, diharapkan untuk membantu berbagai kesulitan ekonomi negara di bidang keuangan. Agak berat bagi pemerintah untuk mengatasi persoalan ekonomi yang membelit dalam persoalan moneter jika hanya mengandalkan kinerja perbankan konvensional yang memiliki beberapa kelemahan yang berpengaruh pada perekonomian nasional. ${ }^{24}$

Selain diharapkan dari kinerja perbankan Islam dapat memulihkan perekonomian Indonesia itu, ada harapan lain dibalik kehadiran perbankan Islam ini. Pemerintah Orde Baru menginginkan dan menggunakan fasilitas bantuan keuangan dan kredit dari islamic Development Bank (IDB).

Upaya ini berhasil dalam bentuk Line of Equity semacam penyertaan modal melalui Bank/Lembaga Keuangan Nasional di negara anggota yang disebut sebagai National Development Financial Institution (NDFI). Ini dilakukan melalui Bank Pembangunan Indonesia (Bapindo) untukUS $\$ 5$ juta bagi pengusaha lemah berupa penyertaan modal paling rendah US $\$ 100.000$ dan paling tinggi
US\$. 2 juta. 25

Usaha-usaha pemerintah Indonesia untuk memperoleh bantuan dari IDB terus berlanjut pada tahun-tahun berikutnya. Seperti mendapatkan Fasilitas Longer Term Trade Financing Šcheme (LTTFS). Suatu fasilitas untuk mendorong ekspor negara anggota dengan cara memberikan pembiayaan ekspor ke negara anggota OKI dengan jangka waktu 2 hingga 5 tahun. Fasilitas ini tidak dikenakan biaya apapun, dan pemerintah Indonesia menunjuk Bank Bumi Daya (BBD) kala itu menangani masalah ini.

Selain LTTFS, pemerintah Indonesia pun memanfaatkan fasilitas yang diberikan IDB; yakni penyertaan modal langsung untuk. proyek-proyek investasi bernilai di atas US\$. 2 juta. Contohnya, PT. Semen Andalas di Aceh sebesar ID. 8,34 juta dan PT. Sumatera Subur Textil (Sumatex Subur) ID.3,50 juta. (Satu /slamic Dollar (ID) setara dengan satu SDR Special Drawing Rights). Dalam hal ini, IDB menunjuk lagi Bapindo menjadi agen line of instalment sale untuk proyek investasi di atas US $\$ 100,000$. IDB juga membantu proyek pembangunan prasarana ekonomi, seperti irigasi, bendungan, jalan dengan fasilitas yang lebih lunak dibanding lembaga moneter international lainnya. Singkatnya, bantuan IDB kepada Indonesia sampai akhir 1991 berjumlah ID.50,74 juta (US $\$ .64,05$ juta) dengan rincian sebagai berikut:

${ }^{23}$ Lihat. Mohtar Mas'oed. 1989. Ekonomi dan Struktur Politik Orde Baru. Jakarta: LP3ES. HIm. 214.

${ }^{24}$ Kelemahan perbankan konvensioanal pada dekade 1990 karena tingkat suku bunga yang tinggi mengakibatkan biaya operasi semakin tinggi pula. Sehingga mengakibatkan hight cost bagi ekonomi Indonesia. Bahkan suku bunga ketika itu mencapai 24 persen. Hanya investor yang menghasilkan keuntungan minimal sekitar 30 persen yang berani melakukan kredit ke perbankan. Lihat Aminuddin. Op.Cit, HIm 293.

${ }^{25}$ Karnaen Perwataatmadja. 1992. Memahami Bank Islam. Yogayakarta: Yayasan Bhakti Wakaf. HIm 62 dalam Aminuddin. Op.Cit. Hlm.295. 


\section{ALOKASI DANA IDB \\ UNTUK INDONESIA HINGGA TAHUN $1991^{26}$}

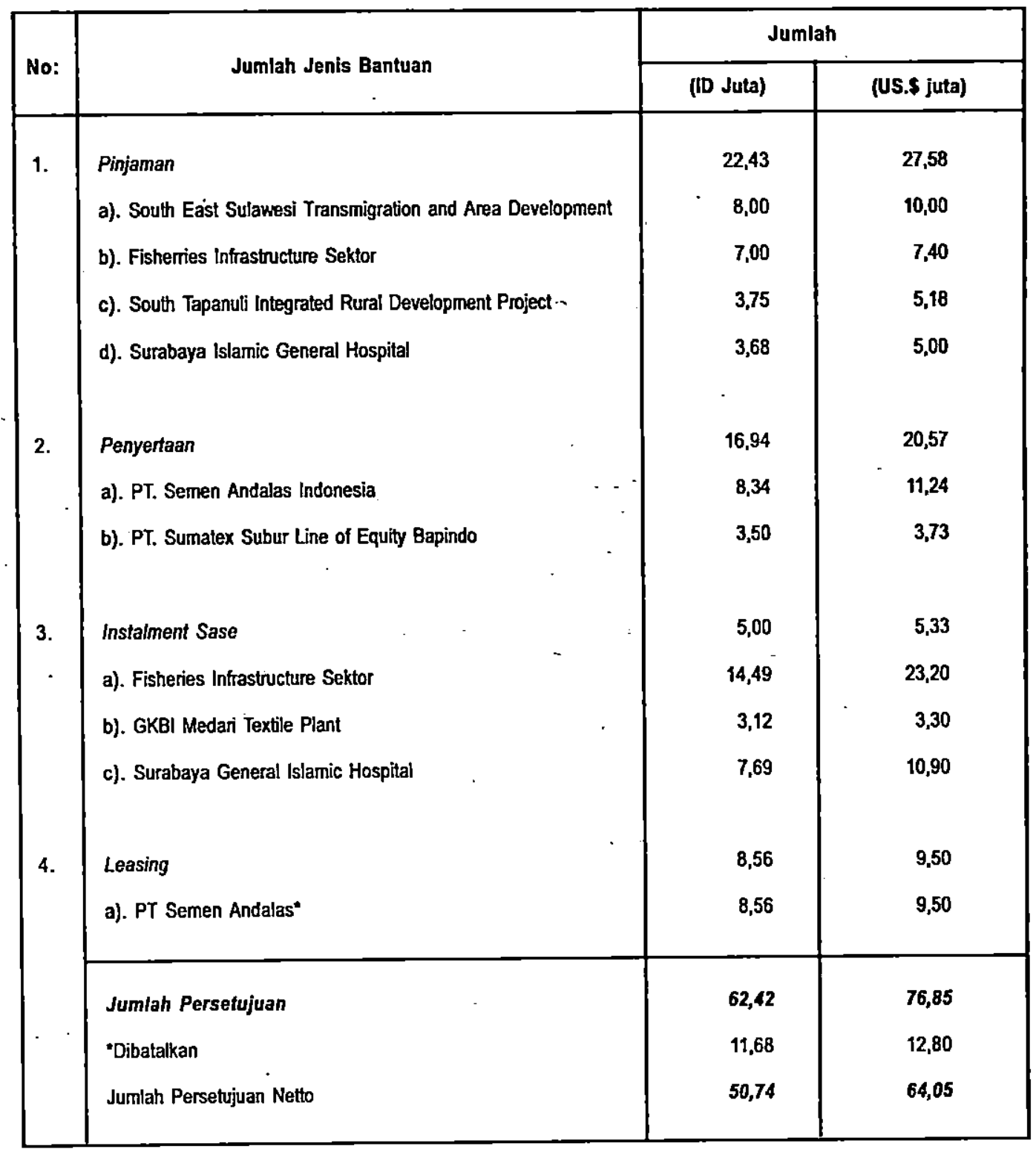

${ }^{25}$ Sumber Ibid. Him. 297. 
Walaupun bantuan dan fasilitas yang diberikan IDB kepada pemerintah Indonesia tidak sebesar bantuan lembaga moneter International lain seperti IMF, namun di tengah mulai suramnya perekonomian Indonesia pada dasawarsa tahun 1990-an itu sungguh sangat berarti.

Harapan pemerintah Indonesia untuk memperoleh kucuran bantuan keuangan dari IDB ternyata disambut baik oleh IDB. Pada 28 November 1995 Presiden Soeharto membuka sidang ke-20 para Gubernur Islamic Development Bank (IDB) di Jakarta. Dalam pidatonya, Presiden menyatakan penghargaannya terhadap IDB dalam membantu perekonomian Indonesia. Dan, mengharapakan IDB semakin meningkatkan perhatiannya terhadap negara anggota (Indonesia) yang mengalami kesulitan bantuan dari luar negeri. Sebagai akibat melesunya perekonomian negara-negara Barat yang dulunya sebagai penyumbang (donor).

Seruan Presiden ini ternyata memperoleh tanggapan positif dari sidang gubernur IDB itu dengan ditandatanganinya 17 pembiayaan proyek senilai US\$.107,333 juta ke negara anggota yang membutuhkan. Termasuk pemberian kepada Indonesia senilai USD.52,227 juta yang diperuntukkan membiayai tiga proyek dengan cara leasing ${ }^{27}$

Bantuan IDB ini sedikit banyaknya sangat berhubungan dan mendukung eksistensi perbankan Islam di Indonesia. Sebagai contoh, IDB tidak memungut bunga pinjaman dari anggotanya. IDB hanya mengenakan biaya administrasi yang tidaklah besar dibandingkan dengan bunga pinjaman dari bantuan international lainnya. Selain itu, IDB lebih sensitif terhadap persoalan umat Islam di negara anggotanya.

Bagaimanapun, yang jelas melalui IDB memberi pesan, bahwa pemerintah Arab Saudi ketika itu siap memberikan komitmen moral dan sumber-sumber ekonominya bagi pencapaian tujuan perbankan Islam.

Refleksi dan Eksistensi UU Perbankan Implikasinya dengan Perbankan Islam di Indonesia.

Eksistensi perbankan Islam di Indonesia adalah sebuah fenomena yang nyata terjadi dan telah diatur secara formal dalam peraturan perundang-undangan, yakni UU. No.10 Tahun 1998 sebagai revisi dari UU No.7 Tahun 1992 tentang Perbankan. Diapun menjalankan operasinya dengan ciri khas atas dasar prinsip ajaran Isiam, baik untuk umat Islam itu sendiri maupun umat-umat lainnya (non Islam). Sebagai lembaga keuangan, perbankan Islam memiliki kelemahan dan kekuatan dibandingkan dengan lembagalembaga keuangan yang lain. Kelemahan utama perbankan Islam berawal dari kedudukannya yang memang sebatas 'mendampingi' sistem perbankan konvensional.

Dalam skala makro, perbankan Islam sesungguhnya berpotensi untuk menciptakan kehidupan perekonomian yang lebih baik.

${ }^{27}$ Bisnis Suara Indonesia. 1 Desember 1995. HIm. 1. Ketiga proyek itu yakni, Pertama, proyek pembangkit listrik tenaga desel untuk daerah terbelakang, khususnya Indonesia Bagian Timur (IBT) sebesar USD.21.08 juta. Kedua, pembiayaan dan perbaikan rumah sakit Syaiful Anwar, Malang senilai USD.9.197 juta, Ketiga, proyek pengadaan perangkat pelatihan bagi siswa Madrasah Aliyah senilai USD.21.95 juta. 
Hanya saja mengingat volume usaha perbankan Islam masih teramat kecil, rasanya kita mesti menunggu beberapa waktu lagi untuk melihat dan menikmatinya secara nyata.

Semua yang diungkapkan di atas sangat berimplikasi dengan eksistensi Undangundang Perbankan itu sendiri. Jika Undangundang perbankan memberi peluang yang besar kepada perbankan Islam untuk memasarkan produk dan jasanya, serta perhatian Bank Indonesia selaku bank sentral serius untuk memajukan perbankan Islam, mustahil perbankan Islam tidak tumbuh pesat seperti di negara-negara lainnya.

Peraturan perundang-undangan yang berlaku sekarang ini, belum menyahuti dan memberi kesempatan penuh kepada dinamika perbankan Islam di Indonesia. Hal itu wajar saja terjadi, sebab dilihat dari fakta historis, bahwa proses pembentukan Undangundang perbankan dilakukan pada masamasa tidak normal. Sehingga kondisi yang demikian, langsung dan tidak langsung berpengaruh terhadap materi dari undangundang yang bersangkutan. Sebagai contoh atas realitas di atas adalah, UU.No.7 Tahun 1992 dibuat pada saat bank-bank sedang berbulan madu dan berpesta pora dalam suasana alam liberalisasi moneter setelah deregulasi yang bersumber dari Pakto 1988. Akibatnya dengan suasana yang demikian sangat mempengaruhi dan mewarnai ketentuan-ketentuan yang terdapat dalam Undang-undang perbankan tersebut. Demikianpun dengan suasana liberalisasi moneter itu, ujung-ujungnya memacu pertumbuhan bank seperti tumbuhnya jamur di musim hujan.

Sebenarnya, fenomena sesaat bukanlah merupakan keadaan yang representatif terhadap dunia perbankan di Indonesia. Sebab, hakikat dunia perbankan adalah harus diatur dan diawasi secara ketat, karena dunia perbankan itu berimplikasi dengan dana masyarakat. Bahkan, berkaitan erat dengan hidup-matinya perekonomian suatu negara.

Sayangnya, pembentuk Undang-undang perbankan tidak mengantisipasi jauh ke depan terhadap dunia perbankan yang sebenarnya. Mereka hanya terpaku kepada era liberalisasi moneter versi Pakto 1988 yang hanya sesaat itu. Oleh sebab itu tidaklah terlalu berlebihan, jika Undang-undang Perbankan No.7 Tahun 1992 tersebut diibaratkan 'sebagai kembang semusim, dan segera layu bila musim berganti'.

Kesempatan era liberalisasi moneter ini, oleh para founding father pemikir perbankan Islam di Indonesia dimanfaatkan. Karena secara historis umat muslim di Indonesia sudah lama menunggu hadirnya perbankan Islam. Namun, selalu terganjal oleh suasana politik dan terbentur dengan tidak adanya aturan yang mengatur dan memberi kesempatan bakal berdirinya perbankan berasaskan syariat Islam di Indonesia. Akhirnya, kesempatan ini digunakan sebaikbaiknya untuk mendirikan perbankan Islam yang diberi nama Bank Muamalat Indonesia (BMI).

Perbankan Islampun terus tumbuh dan berkembang sesuai aturan perundang-undang yang berlaku, meski akhirnya undang-undang perbankan direvisi dengan UU.No.10 Tahun 1998 yang berlaku hingga kini. Tidak jauh beda dengan UU.No.7 Tahun 1992, Undangundang No.10 Tahun 1998 inipun dibuat, justru pada saat keadaan perbankan dalam posisi serba susah dan kacau balau. Akibat dari jorjoran pemberian kredit, maupun akibat 
kesemrawutan policy pemerintah di bidang perbankan, serta akibat krisis moneter yang merusak perekonomian Indonesia termasuk bidang perbankan.

Tindakan yang sangat mengejutkan, ketika pemerintah pada tanggal 1 November 1997 mengumumkan likuidasi 16 bank swasta. Tindakan ini dianggap tak ubahnya sekadar 'cuci piring' setelah pesta pora perbankan di era pakto 1988. Implikasinya dengan UU.No.10 Tahun 1998 yang disahkan pemerintah pada tanggal 10 November 1998 oleh Presiden BJ.Habibie belum menyahuti terhadap perbankan Islam secara utuh. Sebab, masih banyak diktum dari pasal-pasal yang belum memberi keleluasan kepada perbankan Islam untuk berkiprah, seperti kebébasan yang dimiliki perbankan konvensional. Padahal keleluasaan perbankan Islam ini sangat penting, sebab adanya perbedaan ketentuan dalam pelaksanaan operasional antara perbankan Islam dengan perbankan konvensional. Seharusnya ketentuan-ketentuan dalam pasalpasal UU.No.10 Tahun 1998 itu perlu disesuaikan dengan aturan syariah Islam. Dengan demikian, diharapkan perbankan Islam yang berasas syariah ini dapat beroperasi secara efektif dan efisien.

Ada beberapa hal atau ketentuan yang tidak tercover dalam UU.No.10 Tahun 1998 sesuai dengan asas perbankan Islam. Di antara ketentuan tersebut adalah:

1. Instrumen yang diperlukan untuk mengatasi likuiditas;
2. Instrumen moneter yang sesuai dengan prinsip syariah untuk keperluan pelaksanaan tugas bank sentral;

3. Standar akuntansi, audit, dan pelaporan;

4. Ketentuan-ketentuan yang mengatur mengenai prinsip kehati-hatian. ${ }^{28}$

Ketentuan-ketentuan sebagaimana disebutkan di atas tidak secara jelas dan tegas diatur dalam UU.No.10 Tahun 1998 maupun peraturan pelaksanaannya. Padahal ketentuan itu sangat diperlukan oleh perbankan Islam. Demi perkembangan perbankan Islam menuju terciptanya elemen dari sistem lembaga keuangan yang dapat menjalankan fungsinya secara baik, mampu berkembang pesat dan bersaing dengan perbankan konvensional di Indonesia khususnya dan dunia umumnya.

Sementara ketentuan lainnya, bagi perbankan Islam dipersamakan dengan perbankan konvensional. Seperti: ketentuan perizinan dalam pengembangan usaha, yaitu pembukaan cabang dan kegiatan usaha; kewajiban pelaporan ke Bank Indonesia; pengawasan intern; penilaian atas prestasi; dan pengenaan sanksi atas pelanggaran.

\section{Prospek Perbankan Islam di Indonesia}

Perbankan Islam memang lahir dan dikembangkan berdasarkan prinsip-prinsip agama Islam. Meski demikian, bukan berarti ia khusus diperuntukkan bagi orang Islam belaka. Sesungguhnya keberadaan perbankan Islam ditujukan juga kepada 
masyarakat nonmuslim. Adanya anggapan, bahwa perbankan Islam di Indonesia hanya dikhususkan untuk orang yang beragama Islam saja, merupakan suatu persepsi yang keliru.

Secara subjektif, pada hakikatnya nilainilai ajaran Islam adalah universal, sebagai rakhmat bagi seluruh alam. Islam tidak pernah melarang umatnya untuk melakukan aktivitas perekonomian dengan umat lain sejauh dilakukan dengan cara yang adil. Secara objektif, diterimanya perbankan Islam di tengah masyarakat non muslim.

Perbankan Islam, tak ubahnya perbankan konvensional lainnya. Dia merupakan lembaga keuangan yan melaksanakan perantaraan keuangan (financial intermediaries) dari pihak-pihak yang kelebihan dana kepada pihak lain yang membutuhkan berdasarkan prinsip ajaran agama Islam. Di antara prinsip tersebut yang paling utama adalah tidak diperkenankannya perbankan untuk meminta atau memberikan bunga kepada nàsabahnya. ${ }^{29}$

Dalam perantaraan keuangan (financial intermediaries), perbankan setidak-tidaknya mempunyai dua fungsi utama, yaitu sebagai tranmisi (tranmission role) dan sebagai lembaga perantara (intermediaries role). Tranmision role berkaitan dengan fungsi peran bank dalam mekanisme pembayaran antara agen-agen ekonomi sebagai konsekuensi dari transaksi yang mereka lakukan. Sementara intermediaries role berkaitan erat dengan fungsi pemberian fasilitas aliran dana dari mereka yang kelebihan dana kepada mereka yang membutuhkan dana. ${ }^{30}$

Prospek perbankan Islam di Indonesia, bila dilihat dari sektor riil cukup memberi harapan positif. Sebab, operasionalisasi perbankan Islam tidak mengenal bunga, dan pendapatannya berasal dari return bagi hasil atas proyek-proyek yang dibiayai atau marjin pembiayaan jual beli barang. Dengan cara yang demikian, dapat dipastikan, bahwa secara teoritis perbankan Islam sangat berkepentingan mendorong kemajuan sektor riil. Hal yang lebih terpenting bagi perbankan Islam adalah betapapun maju dan berkembangnya tetap tidak akan pernah meninggalkan sektor rill, karena dari sektor inilah aktivitas perbankan muncul.

Beda dengan sistem perbankan konvensional, sektor moneter telah berkembang jauh meninggalkan sektor rill ini. Hal ini dikarenakan, dengan adanya bunga,

29Lihat Q.S. Ar-Rum: 39, Q.S. An-Nisaa:160-161; Q.S. Ali Imran: 130, Q.S.Al-Baqarah: 278-279, serta Hadits-hadits yang diriwayatkan oleh Bukhari, Muslim, Ibnu Majah, dan lain-lain. Selan itu, lihat keputusan Sidang Organisasi Konferensi Islam (OKI) kedua di Pakistan (1970), Fatwa Múfti Negara Mesir, Konsul Kajian Dunia di Kairo (1965), Akademi Liga Muslim Dunia, dan Pimpinan Pusat Dakwah Penyuluhan Kajian Islam dan Fatwa Arab Saudi.

30 Lihat Mayer (et.al), 1984; Pasrington, 1989; Godhart, 1989, dalam Insukindro. 1993. Ekonomi Uang dan Bank, Teori dan Pengalamabn Indonesia. Yogyakarta, BPFE. HIm. 25 dikutip kembali, Akhmad Akbar Susanto. "Bank Syariah di Indonesia, Euphoria Agama?" Jurnal Ekonomi dan Pembangunan Bangsa. Edisi 6. Yogyakarta: HIMIESPA-UGM. 2001. HIm.161. 
uang telah bergeser dari sekedar alat tukar menjadi barang komoditi. ${ }^{31}$ tak menutup kemungkinan hal itu bernuansa spekulasi dan mengarah kepada bentuk judi.

Dalam skala makro, keberadaan perbankan Islam dapat mengurangi laju inflasi yang diakibatkan oleh tekanan tingkat suku bunga. Inflasi yang dicirikan dengan naiknya harga barang dan jasa dapat terjadi karena naiknya biaya produksi (cost push inflation), maupun karena supply barang dan jasa yang menurun (permintaan > penawaran, demand pull inflation). Hanya saja mengingat eksisitensi perbankan islam di Indonesia masih sangat minim, maka manfaat inipun belum cukup signifikan bagi perbaikan kondisi perekonomian kita.

Perkembangan kondisi perbankan Islam di Indonesia dewasa ini, belumlah semarak perkembangan dunia perbankan Islam di negara-negara belahan dunia Islam lainnya. Kondisi yang demikian, karena pengaruh dari situasi perbankan nasional Indonesia yang melancarkan strategi, bahwa penetapan bunga bank merupakan alat kontraksi moneter. Bank sentral masih menggunakan policy penetapan bunga tinggi untuk mengatasi inflasi. Sementara dalam sistem perbankan Islam, seperti kita ketahui adalah mengabaikan apa yang namanya bunga. Akibat pengaruh itu menyebabkan perkembangan perbankan Islam di Indonesia kurang begitu menguntungkan, dan kurang mendapat perhatian dari masyarakat, bahkan pemerintah.

Langkah yang ditempuh Bank Sentral (Bank Indonesia) dengan menetapkan suku bunga SBI yang tinggi, pernah mencapai $67 \%$ telah membuat sektor riil makin terpuruk. Apalagi dengan siklus moneter dan perekonomian Indonesia yang masih mengambang seperti sekarang ini. Sebenarnya, sekarang ini saat yang tepat bagi perbankan Islam untuk menunjukkan eksisitensi dirinya dalam kancah persaingan sebagai lembaga keuangan dengan perbankan konvensional di Indonesia. Sebab, dengan kondisi SBI yang tinggi itu, semakin memberi peluang bagi perkembangan perbankan Islam untuk menarik perhatian kalangan dunia usaha.

Proposisi di atas dapat diindikasikan dengan ilustrasi selama ini pengusaha yang sudah terbiasa dengan kredit perbaṇkan konvensional, dapat diyakinkan harus berpaling kepada produk dan jasa perbankan Islam. Langkah berpaling ini merupakan aiternatif mencegah kerugian pihak pengusaha. Sebab, sebagaimana telah dijelaskan sebelumnya, profit and loss sharing principle dalam teransaksi syariah lebih memberikan kepastian kepada pengusaha untuk memperoleh fasilitas pembiayaan guna tidak memikul beban bunga bila usahanya gagal. Sementara melalui kredit perbankan

${ }^{31}$ Menurut catatan Maurice Allais peraih Nobel Ekonomi 1998, dari US $\$ .420$ miliar uang yang beredar setiap harinya, hanya US\$.12,4 miliar atau 2,95 persen yang digunakan untuk keperiuan transaksi. Dan sisanya berputar-putar dalam aktivitas spekulasi dan judi. Lihat, Samsul Falah. "Perbankan Syariah; Sebuah Alternatif Perbankan Indonesia." Makalah Seminar dan diskusi Ilmiah Nasional Mahasiswa Akuntansi. Purwekerto: Universitas Jendral Soedirman. 16 Mei 2000. 
konvensional semata-mata tertumpu kepada diktum perjanjian antara kreditor dan debitor yang telah disepakati. Pokoknya tidak memperdulikan apakah debitor tersebut rugi atau untung dalam usahanya, yang jelas harus menepati ketentuan bunga yang telah diperjanjikan bersama.

Prospek perbankan Islam di Indonesia terbuka lebar dan mampu bersaing dengan perbankan konvensional, meskipun sekarang masih banyak kendala yang dihadapinya. Dengan bahasa lain, Sutan Remi Sjahdeini mengatakan pertumbuhan dan perkembangan perbankan Islam di Indonesia belum menggembirakan, namun berpotensi besar untuk marak ${ }^{32}$ Beda dengan perbankan Islam yang ada di Saudi Arabia, Pakistan, Kuwait, Emirat Arab dan Qatar, bahkan Malaysia.

Ada beberapa pertimbangan dan alasan akan membaiknya prospek perbankan Islam di Indonesia kelak dikemudian hari. Di antaranya adalah:

1. Peluang pasar untuk lembaga keuangan Islam masih terbuka lebar. Mengingat, mayoritas penduduk Indonesia adalah muslim. Potensi mayoritas muslim ini harus disinergikan dan menjadi kekuatan modal bagi perbankan Islam. Konteksnya hal. ini ada implikasinya terhadap pelaksanaan ibadah haji. Bukankah, umat muslim Indonesia merupakan jumlah mayoritas dari peserta haji di dunia? Kalau perbankan Islam mampu menggaet dana ibadah haji ini, tentu menjadi sumber yang besar bagi permodalan dan pembiayaan bagi perbankan Islam. Sebagai contoh, pada musim haji tahun 2002 lalu, jumlah peserta jemaah haji indonesia hampir 200.000 orang. Seandainya besarnya biaya ongkos haji lebih kurang Rp.30 juta disetor melalui perbankan Islam. Maka, otomatis dana yang bisa diserap oleh perbankan Islam sebagai sumber pembiayaan sebesar Rp.6.000.000.000.000 (Enam Triliun Rupiah). Suatu jumlah yang pantastis, hanya dalam satu kegiatan haji saja.

Contoh lain lagi adalah, pengelolaan dana simpanan atau tabunga Mudharabah misalnya. Dari sekitar 200 juta penduduk. Indonesia, yang katanya 90 persen beragama Islam (180 juta orang). Bila separuh atau 50 persen dari 180 juta orang itu menabung dalam setiap bulannya minimal Rp. 10.000 saja, maka dana simpanan yan terkumpul setiap bulannya sebesar: (50/100 x 180 juta orang $\times$ Rp. $10.000 \times 1$ bln $)=90$ juta orang $\times$ Rp. $10.000 \times 1 \mathrm{bln}=$ Rp. 900.000 .000 .000 (Sembilan Ratus Miliar Rupiah) perbulan. Kalau pertahun, maka dana yang terkumpul sekadar dari tabungan ini saja sebesar Rp. $900.000 .000 .000 \times 12=$ Rp.10.800.000.000.000 (Sepuluh Triliun Delapan Ratus Miliar Rupiah).

Potensi besar dari jumlah mayoritas umat Islam Indonesia ini, menurut hemat penulis belum dikembangkan dan dimanfaatkan secara oftimal oleh pengelola perbankan Islam. Masih banyak sumber dana dari pemanfaatan jumlah mayoritas umat Islam ini, misalnya pembayaran zakat mal (harta) atau zakat

32Lihat Sutan Remi Sjahdeini. Perbankan Islam..., Op.Cit. HIm. 194. 
fitrah. Sebagai contoh yang gampang adalah sumber dana zakat fitrah sebesar Rp.7.500/jiwa. Dari 180 juta masyarakat muslim Indonesia itu, katakanlah yang membayar zakat separuh saja ( 50 persen). Jika hal ini dapat diberdayakan oleh perbankan Islam, maka dana yang terkumpul setiap tahunnya berputar di perbankan Islam sebesar $=90.000 .000$ jiwa $\times$ Rp. $7.500=$ Rp. 675.000 .000 .000 . (Enam Ratus Tujuh Puluh Lima Miliar Rupiah). Jumlah ini merupakan putaran modal yang cukup besar, sembari menunggu pemberian kepada person yang berhak menerimanya.

Dengan potensi besar itu, bila perbankan Islam mampu meyakinkan umat muslim Indonesia tentang eksistensi dirinya, maka perbankan Islam Indonesia akan cemerlang. Tentunya bagi umat muslim Indonesia sendiri tidak ada yang kekurangan . modal untuk mengembangkan usahanya. Dengan demikian, secara otomatis, bahwa kemiskinan yang menjadi musuh Islam akan terkikis di muka bumi Indonesia.

2. Belajar dari pengalaman kondisi suramnya perekonomian Indonesia sekarang ini, menjadi kesempatan baik bagi perbankan Islam untuk lebih menunjukkan jati dirinya. Perbankan Islam dalam suasana perekonomian yang sulit, temyata mampu mempertahanan diri dari serangan badai moneter seperti yang terjadi pada perbankan konvensional. Alhasil, banyak para pengusaha yang sudah mulai melirik kepada sistem perbankan Islam.

Demikianpun dengan perbankan konvensional sendiri lambat-laun menyadari akan kebaikan dari sistem yang ditawarkan perbankan Islam. Sehingga banyak pengelola perbankan konvensional mengkonversikan diri ke sistem perbankan . Islam. Bahkan, kalangan pengamat ekonomi kita meskipun masih malu-malu, tapi sudah mengakui, bahwa sistem yang dijalankan perbankan Islam dapat memberi kontribusi terhadap penyelesaian krisis ekonomi di indonesia khususnya dan belahan dunia lain umumnya.

3. Mengacu kepada asumsi dasar lembaga keuangan Islam, bahwa uang sebagai media transaksi membuat banyak lembaga keuangan Islam menahan diri dari melakukan transasksi spekulatif dengan valuta asing. Oleh sebab itu perbankan Islam tidak terkena resiko nilai tukar. Sebab, perbankan Islam menghindari unsur spekulatif dalam transaksi valuta asing, beda halnya dengan perbankan konvensional yang justru sebaliknya.

Oleh karenanya, perbankan Islam dianggap mendukung mata uang lokal dan mendukung pemerintah dalam menciptakan hard currency (stabilitas mata uang di dalam dan diluar negeri) guna menghindari spekulasi pasar.

Prospektif perbankan İslam sebagaimana dikemukakan di atas akan lebih cepat dan dapat direspon serta ditindaklanjuti dengan baik oleh imasyarakat, jika dilakukan dengan berbagai upaya dan strategi.

Strategi pengembangan perbankan Islam diarahkan untuk meningkatkan kompetensi usaha yang sejajar dengan sistem perbankan konvensional. Dilakukan 
secara komprehensif dengan mengacu pada analisis kekuatan dan kelemahan perbankan Islam saat ini. Misalnya, melalui peningkatan keahlian Sumber Daya Manusia (SDM), penyempurnaan ketentuan peraturan perundangundangan perbankan, dan program sosialisasi.

Adapun fokus utama strategi pengembängan sistem perbankan Islam meliputi hal-hal sebagai berikut: ${ }^{33}$

1. Penyempurnaan ketentuan Peraturan Perundang-undangan yang berhubungan dengan masalah Perbankan. Dalam hal ini perlu diupayakan penyesuaian perangkat dasar Undang-undang Bank Sentral, Undang-undang Perbankan, dan penyusunan perangkat-perangkat ketentuan pendukung kegiatan operasional perbankan Islam. Meskipun, perbankan Islam telah diatur di dalam UU.No.10 Tahun 1998 sebagai revisi dari UU.No.7 Tahun 1992 tentang Perbankan telah diterapkan pasal-pasal yang membuka peluang pengembangan yang lebih luas bagi perbankan Islam. Namun, ketentuan itu masih memberi kesan kelemahan kepada aktivitas perbankan Islam, karena terbentur dengan peraturan perundang-undangan lainnya. Misalnya, terbentur dengan UU.No.23 tahun 1999 Tentang Bank Indonesia, terutama dalam masalah likuiditas.

2. Pengembangan Jaringan Perbankan Islam. Pengembangan ini ditujukan untuk menyediakan akses yang lebih luas kepada masyarakat dalam mendapatkan pelayanan jasa perbankan Islam. Cäranya, dengan melakukan peningkatan kualitas perbankan Islam, baik itu oleh bank umumnya maupun BPRnya. Selain itu, harus melakukan perubahan kegiatan usaha perbankan konvensional untuk melakukan kegiatan usaha dengan sistem perbankan Islam. Dan, yang terakhir caranya adalah membuka kantor cabang perbankan Islam, baik itu oleh perbankan konvensional maupun bank umum perbankan Islam sendiri.

3. Pengembangan piranti moneter: Langkah ini dilakukan untuk mendukung kebijakan moneter dan kegiatan usaha perbankan Islam. Tujuan pengembangan piranti ini adalah untuk dapat membantu pengembangan pasar uang perbankan Islam itu sendiri.

4. Pelaksanaan Kegiatan Sosialisasi Perbankan Islam. Tujuan dari strategi ini adalah untuk memberikan informasi yang lengkap dan benar mengenai kegiatan usaha perbankan Islam kepada masyarakat, baik itu kalangan pengusaha, perbankan, maupun masyarakat umum Realitas prospek perbankan Islam di Indonesia, bila kita lihat dari contoh kasus Bank Muamalat Indonesia, sekarang ini menapaki kemajuan bila dibandingkan dengan beberapa tahun silam. Kondisi perkembangan ini, konon sejak Indonesia dilanda badai krisis sedari 1998 lalu. Sehinggamenyebabkan banyak

${ }^{33}$ Lihat Muhammad Syafi'i Antonio. 2001. Bank Syariah dari Teori ke Praktik. Jakarta: Gema Insani Press. Hlm.227-230. Bandingkan dengan Sutan Remi Sjahdeini. Perbankan Islam..., Op.Cit. HIm. 194-196. 
Naziarto.SR. Perbankan Islam di Indonesia: Implikasinya dengan Politik, Hukum, dan Islam

para pengusaha, bahkan kalangan perbankan beralih ke sektor perbankan Islam, karena dirasakan sangat menguntungkan.

Perkembangan perbankan Islam sebagai contohnya adalah Bank Muamalat Indonesia dengan satu kantor induk (pusat) beralamat di Gedung Athaloka, Jl. Jendral Sudirman No. 2 Jakarta. Kini telah memiliki sebelas cabang tersebar di beberapa propinsi di Indonesia. Antara lain, di Jl. Fatmawati-Jakarta; SerpongTangerang; Kalimalang-Bekasi; Bandung; Semarang; Surabaya; Makassar, Balikpapapan; Medan; Pekanbaru; Pekalongan; dan Bogor. Sementara Cabang pembantunya berlokasi antara lain di Cipulir-Jakarta; Mas MansyurSurabaya; Salman-Bandung; CihampelasBandung; Rawamangun-JakartaTimur; Depok-Jakarta. Untuk kantor kas berjumlah 34 kantor tersebar di beberapa propinsi di Indonesia.

Kondisi kemajuan itu terlihat dari laporan keuangan Bank Muamalat Indonesia sebagai saiah satu contoh perbankan Islam di Indonesia untuk kondisi usaha pada tahun 2000 dan 2001 yang lalu. Dalam laporan yang diumumkan secara terbuka dan dimuat harian Republika, Selasa 30 April 2002 memuat di antaranya tentang neraca keuangan pada tahun 2000 dan 2001. Neraca ini menggambarkan kondisi keuangan dan segala usaha yang dilakukan perbankan Islam (BMI) berupa aktiva dan pembiayaan berupa pasiva menunjukkan, bahwa terjadi peningkatan sebesar Rp.437.434 juta untuk tahun 2001. (Rp.1.564.422-dalam jutaan ru- piah pada tahun 2001 dan Rp.1.126.988 pada tahun 2000). ${ }^{34}$

\section{Simpulan}

Hadirnnya perbankan Islam di Indonesia tidak teriepas dari kondisi riil politik dan kekuasaan pemerintahan (Orde Baru) di bawah 'fower center' Soeharto selaku mantan Presiden ketika itu. Karena terjadi 'magnit' tarikmenarik peran dan pengaruh umat Islam mayoritas ke kancah politik untuk mempertahankan kekuasaannya. Realitas hadirnya perbankan Islam di Juni 1992 itu merupakan wujud dimensi ekonomi-politik akomodasi negara Orde Baru dengan kekuatan Islam.

Sebagai lembaga keuangan, perbankan Islam memiliki kelemahan dan kekuatan dibandingkan dengan lembaga-lembaga keuangan yang lain. Kelemahan utama perbankan Islam berawal dari kedudukannya yang memang sebatas 'mendampingi' sistem perbankan konvensional. Kekuatannya dalam skala makro, perbankan Islam sesungguhnya berpotensi untuk menciptakan kehidupan perekonomian yang lebih baik.

Peraturan perundang-undangan perbankan yang berlaku sekarang ini, belum menyahuti dan memberi kesempatan penuh kepada dinamika perbankan Islam di Indonesia. Hal itu wajar saja terjadi, sebab dilihat dari fakta historis, bahwa prộses pembentukan Undang-undang perbankan dilakukan pada masa-masa tidak normal. Sehingga kondisi yang demikian, langsung dan tidak langsung

34Lihat Republika. Selasa 30 April 2002. 
berpengaruh terhadap materi dari undangundang yang bersangkutan. UU.No.7 Tahun 1992 dibuat pada saat bank-bank sedang berbulan madu dan berpesta pora dalam suasana alam liberalisasi moneter setelah deregulasi Pakto 1988. Akibatnya dengan suasana yang demikian sangat mempengaruhi dan mewarnai ketentuanketentuan yang terdapat dalam Undangundang perbankan tersebut. Demikianpun dengan suasana liberalisasi moneter itu, ujung-ujungnya memacu pertumbuhan bank seperti tumbuhnya jamur di musim hujan. Pembentukan Undang-undang perbankan tidak mengantisipasi jauh ke depan terhadap dunia perbankan yang sebenarnya. Mereka hanya terpaku kepada era liberalisasi moneter versi Pakto 1988 yang hanya sesaat itu. Oleh sebab itu tidaklah terlalu beriebihan, jika. Undang-undang Perbankan No.7 Tahun 1992 tersebut diibaratkan 'sebagai kembang semusim', dan segera 'layu bila musim berganti'. Demikianpun dengan UU No 10 Tahun 1998 sebagai revisi UU No. 7 Tahun 1992 diibaratkan laksana 'petinju kalah bertanding', dan 'tinggal merintih sakitnya'. $\square$

\section{Daftar Pustaka}

Al-Qur'an dan Terjemahannya, Departemen Gama RI.

Aminuddin. 1999. Kekuatan Is/am dan Pergulatan Kekuasaan di Indonesia, Sebelum dan Sesudah runtuhnya Rezim Soeharto. Yogyakarta: Pustaka Pelajar.

Antonio, Muhammad Syafi'i. 2001. Bank Syariah dari Teori ke Praktik. Jakarta: Gema Insani Press.
Azhari, Muhamad Tahir. 1992. Negara Hukum, Suatu Studi Tentang Prinsip-Prinsipnya Dilihat Dari Segi Hukum Islam, Implimentasinya Pada Periode Negara Madinah dan Masa Kini. Jakarta: Bulan Bintang.

Effendy, Bachtiar. 2000. Repolitisasi Islam, Pernahkah Islam Berhenti Berpolitik. Bandung: Mizan.

Falah, Samsul. "Perbankan Syariah, Sebuah Alternatif Perbankan Indonesia." Makalah Seminar dan diskusi Ilmiah Nasional Mahasiswa Akuntansi. Purwekerto: Universitas Jendral Soedirman. 16 Mei 2000.

Hefner, Robert W.. 'Islamisasi Kapitalisme: Tentang pembentukan Bank Islam Pertama di Indonesia", Dalam Mark R. Woodward, (ed). 1998. Jalan Baru Islam, Memetakan Paradigma Mutkahir Islam Indonesia. Bandung: Mizan.

Hefner, Robert W.. 'Islamisasi Kapitalisme:

Tentang pembentukan Bank Islam Pertama di Indonesia", dalam Mark $R$. Woodward, (ed). 1998. Jalan Baru Islam, Memetakan Paradigma Mutkahir Islam Indonesia. Bandung: Mizan.

insukindro. 1993. Ekonomi Uang dan Bank, Teori dan Pengalamabn Indonesia. Yogyakarta, BPFE. HIm. 25 dikutip kembali, Akhmad Akbar Susanto. "Bank Syariah di Indonesia, Euphoria Agama?" Jurnal Ekonomi dan Pembangunan Bangsa. Edisi 6. Yogyakarta: HIMIESPA-UGM. 2001.

Liddle, R. William. 1992. "Indonesia's Democratic Past and Futer." Com- 
parative Pólitics 24 , No. 8 . Tanggal 9 November 1992.

Perwataatmadja, Karnaen. 1992. Memahami Bank Islam. Yogyakarta: Yayasan Bhakti Wakaf.

Rachbini, Didik J. "Assalamu'alaikum, Kiyai Masuk Bank." Info Bank No. 124, April 1990.
Warta Ekonomi. "Mulus Bagai Jalan Tol." Tanggal 28 Oktober 1991.

Bisnis Suara Indonesia. 1 Desember 1995. Editor. 5, No. 9, Tanggal 16 November 1991. Pelita. 2 Nopember 1991.

Republika. Selasa 30 April 2002.

จ จ จ 